\title{
Response to Sean Wilentz's "Against Exceptionalism: Class Consciousness and the American Labor Movement: 1790-1920"
}

\author{
Steven Sapolsky \\ University of Pittsburgh
}

I agree with Sean Wilentz that theories of American exceptionalism which rest on essentialist assumptions are ahistorical and objectionable on that account. But historical analysis of contexts and periods may well yield the conclusion that the United States, in a particular period, was so different from Europe as to be an exception to the general pattern of capitalist nation-states in that period. Perhaps the word "exception" should not be used because of its associations with ahistorical theories. But I think it can be used to describe the United States from the 1920s through the post-World War II boom. As we enter a new era of world capitalism in our times, perhaps the differences between the United States and other countries will narrow once again. This is possible, and if it happens, American exceptionalism will be no more. During the golden age of American consumer capitalism and the American dominance of the world, however, I don't see how Wilentz can insist that the United States and its labor movement were merely different. Surely, the cumulative impact of the events of the period from 1890 to 1920 (the era of organized capitalism, the second industrial revolution, mass communications and mass politics, imperialism, world war and revolution) resulted in a profound divergence between the United States and Europe. Wilentz does not acknowledge how crucial this period was for the rest of the twentieth century. This is why he does not see that it was the era of the rise of mass socialist parties almost everywhere in Europe and not just in Germany. Although I do think the United States became an exception by the 1920s, I do not think this was an inevitable development. Not only do I agree with Wilentz about the nineteenth century, but I also agree that the American labor movement of the early twentieth century was more anticapitalist than the traditional wisdom has it. A British-style laborism was in the making, and why it did not crystallize in more places than it did is an open question. My thesis on Chicago addresses this question and it will show that there was more class consciousness at the grass-roots of the AFL than even Wilentz suggests. Nevertheless, by the time labor turbulence subsided after World War I, the outcome was clear. Just as Wilentz's framework glosses over 
the new world of 1890 to 1920 , so it cannot explain the brave new world of 1920-70.

To get a handle on comparative labor history, it is useful to distinguish between Britain and Continental Europe. To tighten his argument, Wilentz should leave the Continent out of the picture and focus on the comparison of the United States to Britain. The special historical relationship between the two countries guarantees that their comparison is more exact and appropriate. The striking similarities in their labor histories are made to order for Wilentz's argument. And, not surprisingly, British historiography has its own obsession for the peculiarities of the British. American labor historians are not the only ones who have to deal with brilliant historians like Hofstadter and Hartz. The history of British socialism from the 1840s to the present has given rise to sophisticated theories of British exceptionalism that are, if anything, more convincing than their American counterparts because they are more historical, being grounded as they are in the world's most extensive labor history. To take a recent example, Ross McKibbin starts his provocative article on "Why Was There no Marxism in Great Britain?" as follows: "Sombart's question might more fruitfully be asked of Britain than of the United States. Britain was similar enough to the Continent to make the differences more puzzling; between America and Europe the contrasts were, in fact, too apparent to allow much of a problem." British exceptionalism is also the favorite theory of some of the British Marxists associated with The New Left Review. They have drawn the overwhelming wrath of E. P. Thompson, ${ }^{2}$ who insists that British peculiarities do not add up to make Britain an exception. The debate is hot and unsettled, just as is the comparable debate about the United States.

Wilentz is offering a Thompsonian argument against American exceptionalism. Curiously enough, I suspect that E. P. Thompson himself believes that the United States is an exception. And I suspect that he would be particularly annoyed by any suggestion that the United States is closely comparable to Britain. But Wilentz must establish that very comparison if his argument is to be successful. On the face of it, there is ample evidence that Wilentz could cite. For the pre-World War I period, for example, many American socialists had good reason to feel as they did, that the United States was more class conscious than Britain. The class struggle was more bitter and explosive, the IWW was creating a revolutionary culture of a scale and vigor unknown in Britain, and the Socialist party was popular with many AFL trade unionists and seemed no less successful than Britain's non-socialist Labour party. Before 1921, the Socialist party did its best, often successfully, to sabotage the many attempts to form labor parties at the local level all over the United States. It felt that the United States was ready for the real thing-a Continental-style Marxist partyeven if Britain wasn't. Why, even Hearstism, that virulent form of Jeffersonian radicalism then very popular in the big cities with its clamor for the destruction of the "Criminal Trusts" and the public ownership of natural monopolies, was 
more radical than British laborism. It was said that the only viable position for socialists to take left of Hearstism was to build a real, revolutionary Socialist party. ${ }^{3}$

By the 1920s, it was clear that American socialists had been wrong. If they had adopted the policy of the British ILP in 1900 rather than 1921 and had helped to form labor parties before World War I, perhaps many more cities would have gone the way of Milwaukee and Minneapolis-St. Paul. It would not have been the first time, or the last, that radical sectarianism has been selfdefeating. On the other hand, the United States and Britain were developing in ways that were sending them down markedly different paths; this would have happened, to a great extent, whatever the policy of the Socialist party. These developments, I think, vindicate Thompson's celebration of British peculiarities. But they cast doubt on Wilentz's claims for the United States. This is not the place to justify my position, but I will close with a list of a few of the developments that $I$ have in mind.

In the nineteenth century, artisan cooperative socialism was no stronger in Britain than it was in the United States, and many fewer producer cooperatives were formed in either country than in France. But consumer cooperation became a mass movement in Britain in the second half of the century, while it never took off in the United States. Through the 1880s, the percent of the work force in unions was about the same in both countries. Thereafter, and down to the present day, a much larger percent of British workers have been organized. ${ }^{4}$ These two facts, taken together, go far to explain the divergence between the British and American labor movements in the early twentieth century. ${ }^{5}$ One more development helps to explain why political laborism crystallized in Britain and not in the United States. Throughout the nineteenth century, the political language of British and American working-class radicalism was remarkably similar. It described society not as divided into classes, but as one vast, virtuous majority that suffered injustice from the political crimes of a tiny, corrupt elite-usually identified as monopolists, aristocrats, predatory special interests, and so forth. It was also a language of patriotism: Workers were proud either of their American Republic or their rights as "freeborn Englishmen." The political practice that went along with this language aimed to create cross-class coalitions; class politics and class consciousness divided the virtuous majority, weakened its power, and wasn't necessary anyway in the struggle against the corrupt elite. Only in the last two decades of the nineteenth century did an increasing number of radical workers in Britain begin to think along very different lines. Instead of explaining injustice with reference to aristocracy and political corruption, they began to describe the source of their problems in a more structural, socioeconomic language, one that focused less on the misdeeds of the wealthy and more on capitalism as a system. At the same time, patriotism was losing its radical connotations. The new type of radicalism in the making was not as closely linked with nationalism as the old had 
been; for a significant number of British workers, their new radicalism was in direct opposition to the new nationalism of the Age of Imperialism. ${ }^{6}$

The result of these shifts in political culture was apparent by the early twentieth century: British working-class radicalism was evolving from liberalism to laborism. Were there comparable changes in working-class political culture in the United States? There were, but I am convinced that the nineteenthcentury language of radicalism was able to reproduce itself and adapt to the early twentieth century much more successfully in the United States than in Britain. One very important example was the modernization of Jeffersonian radicalism in the hands of people like Altgeld, Darrow, and Hearst. Most of the radicals who dominated the Chicago Federation of Labor after 1900 thought of themselves as Jeffersonians. It was only after a long and painful process that they converted to laborism by the end of World War I. Their equivalents in Britain would have been pioneers of the Labor party 20 years earlier. The result in the United States was that the patriotic radicalism of Bryan, Hearst, Theodore Roosevelt, and Woodrow Wilson captured most of the labor radicalism of the time. Add all these developments and many more, and I think the following result: a laborist Britain that is different from the socialist Continent, although sharing with it a solidified and institutionalized workingclass consciousness, and a United States that is in a category of its own.

\section{NOTES}

1. Ross McKibbin, "Why Was There No Marxism in Great Britain?" The English Historical Review 99 (April 1984).

2. E. P. Thompson, "The Peculiarities of the English," in The Poverty of Theory and Other Essays (New York, 1978).

3. See, for example, William E. Walling, Socialism as It Is: A Survey of the World-Wide Revolutionary Movement (New York, 1912) 215, and George D. Herron, "The British Labor Party and American Socialism," The Miners Magazine, 7 January, 1909, reprinted from the New York socialist Daily Call.

4. Philip S. Bagwell and G. E. Mingay, Britain and America: A Study of Economic Change, 1850-1939 (New York, 1970), 204.

5. For the role of the cooperative movement in the grass-roots of laborism, see the provocative comments in "Editorial: The Labour Party and Social Democracy," History Workshop Journal 12 (Autumn 1981).

6. W. D. Rubinstein, "The End of 'Old Corruption' in Britain, 1780-1860," Past and Present 101 (November 1983), 81-82; Hugh Cunningham, "The Language of Patriotism, 1750-1914," History Workshop Journal 12 (Autumn 1981). 